\title{
Capital structure effects on banking performance: a case study of Jordan
}

\author{
Khalaf Taani \\ Department of Banking \& Finance, Faculty of Finance \& Administrative Sciences, Irbid National University, Irbid, Jordan
}

\section{Email address:}

ktaani@yahoo.com

\section{To cite this article:}

Khalaf Taani. Capital Structure Effects on Banking Performance: A Case Study of Jordan. International Journal of Economics, Finance and Management Sciences. Vol. 1, No. 5, 2013, pp. 227-233. doi: 10.11648/j.ijefm.20130105.13

\begin{abstract}
This study examines the impact of capital structure on performance of Jordanian banks. The annual financial statements of 12 commercial banks listed on Amman Stock Exchange were used for this study which covers a period of five (5) years from 2007-2011. Multiple regressions was applied on performance indicators such as Net Profit (NP), Return on Capital Employed (ROCE), Return on Equity (ROE) and Net Interest Margin (NIM) as well as Total Debt to Total Funds (TDTF) and Total Debt to Total Equity (TDTE) as capital structure variables. Multiple regression models are applied to estimate the relationship between capital structure and banking performance. The results show that bank performance, which is measured by net profit, return on capital employed and net interest margin is to be significantly and positively associated with total debt; while total debt is found to be insignificant in determining return on equity in the banking industry of Jordan.
\end{abstract}

Keywords: Capital structure, Bank performance, Total debt, Jordan

\section{Introduction}

This study focuses on capital structure \& profitability of listed banks in the Banks sector. Capital structure is one of the major topics among scholars in finance. Capital Structure in finance term means the way a firm finances his assets across the blend of debt, equity or hybrid securities (Saad, 2010). The concept is generally described as the combination of debt $\&$ equity that make the total capital of firms. The proportion of debt to equity is a strategic choice of corporate managers. Capital structure decision is the vital one since the profitability of an enterprise is directly affected by such decision. Hence, proper care and attention need to be given while determining capital structure decision. In the statement of affairs of an enterprise, the overall position of the enterprise regarding all kinds of assets, liabilities are shown. Capital is a vital part of that statement. The term "capital structure" of an enterprise is actually a combination of equity shares, preference shares and long term debts. A cautious attention has to be paid as far as the optimum capital structure is concerned with unplanned capital structure, companies may fail to economize the use of their funds. Consequently, it is being increasingly realized that a company should plan its capital structure to maximize the use of funds and to be able to adapt more easily to the changing conditions, (Pandey, 2009).

The relationship between capital structure and profitability is one that received considerable attention in the finance literature. Nonetheless, in the context of the banking industry, the subject has received a limited research attention. The study regarding the effects of capital structure on profitability will help us to know the potential problems in performance and capital structure. The modern industrial firm must conduct its business in a highly complex and competitive business environment. Therefore, these types of research findings will be benefited in selecting the capital structure to achieve the optimum level of firm's profitability.

The purpose of conducting this study is to measure the impact of capital structure on banking performance to provide empirical evidence regarding Jordanian banking sector over a period of 2007 to 2011.

\section{Literature Review}

The literature on the relationship between firm performance and capital structure has produced mixed results. Ebaid (2009) examined the capital structure and performance of firms, basically the aim was to check the relationship between debt level and financial performance 
of companies (listed at Egyptian stock exchange during the period of 1997 to 2005). By using the three accounting based measure of performance (ROA) return on assets (ROE) return on equity and gross profit margin. He found that there is negative significant influence of short term debt (STD) and the Total debt (TD) on the financial performance measured by the return on asset (ROA) but no significant relationship fond between long term debt (LTD) and this measure of financial performance. He also proposed that there is not significant influence of the debt (TD, STD and LTD) on financial performance measured by both of gross profit margin and Return on equity .The results also indicated that control variable firm size has no significant effect on the firm's performance. In this research paper least squares regression model was used to check the performance of the firms.

San and Heng (2011) they examined that the relationship of capital structure and corporate performance of firms before and during 2007 crisis, all 49 construction companies are taken from Malaysia which were listed in Main board of Bursa Malaysia from 2005 to 2008 these forty nine companies are divided in three units like small, medium and large or big size. Always financial crisis are occurred by the poor corporate performance, in the Malaysia construction industries and construction activates are the major source of growth and development in Malaysia, in this research (capital structure) independent variables are used Long term debt to capital (LDC), debt to capital (DC), debt to asset (DA), debt to equity market value (DEMV), debt to common equity (DCE), long term debt to common equity (LDCE) and (Corporate performance) dependent variables are return on capital (ROC), return on equity (ROE), return on asset (ROA), earnings per share (EPS), operating margin (OM) and net margin (NM). The pooling regression model is employed to test the influence of capital structure on the company's performance method of ordinary least square (OLS) is used to estimate the regression line (OLS) is used to minimize the error in estimated and actual points. The result shows that, there is relationship between capital structure and corporate performance, in the interim the results also indicate that there are no relationship between the various variables that are examined in this study. For the big construction companies only return on capital (ROC) and Earnings per share (EPS) for large construction companies have significant relationship with capital structure, mean while Return on capital (ROC) and Debt equity to market value (DEMV) are the most correlated and showing the strongest relationship among all the variables examined. Basically, debt equity to market value (DEMV), long term debt to capital (LDC) and debt to capital (DC) have direct influence on corporate performance of the large companies and other independent variables don't affect the dependant variables. Debt to capital (DC) has direct impact on corporate performance of small companies and yet other independant variables don't affect the dependent variables.

Ahmad and Abdullah and Roslan (2012) investigated the impact of capital structure on firm performance by analyzing the relationship between operating performance of Malaysian firms. Modigliani and Miller (1958) have theoretically argued and proved that capital structure is irrelevant in a perfect market condition, characterized by the capital market with no taxes, no transaction costs and homogenous expectations; other works that assume several market imperfections on the contrary suggested that capital structure decisions are relevant since it can affect shareholders wealth. Modigliani and Miller (1963) in existence of corporate taxes suggested that firms should use as much debt capital as possible in order to maximize their value by maximizing the interest tax shield. The dependent variables used in this research are ROA (Return on asset), ROE (return on equity) and control variable are firm size (SIZE), sales growth (SG), growth (AG), firm efficiency and independent variables are long-term debt (LTD), short term debt (STD) and total debt (TD). All the companies are public listed organizations in the Malaysia, specifically the Modigliani-Miller theorem; trade-off theory and pecking order theory were reviewed to provide sufficient understanding of how much capital structure could affect firm's performance. This study covers tow major sectors consumers and industrials sectors 58 firm's sample starting from 2005 to 2010 with total of 358 observations and two general pooled regression models are used. Findings of the study validated that STD and TD have significant relationship with return on asset (ROA) while Return on equity (ROE) and all capital structure indicators have significant relationship. The significant relationship between short-term debt, long-term debt and total debt with ROE is consistent with the findings of (Abor 2005; Mesquita and Lara 2003). The positive significant relationship between long-term debts with ROA is coherent with the findings of (Philips and Sipahioglu 2004; Grossman and Hart 1986). Which indicates that higher levels of debt in the firm's capital structure is directly, associated with higher performance levels and other finding is that Return on Equity (ROE) is not significant associated with all the capital structure variables.

Amidu (2007) conducted a study to investigate the dynamics involved in the determination of the capital structure of the Ghana banks. The dependent variables used in this paper are the leverage (LEV) is total debts divided by total capital; short-term debt ratio (SHORT) is total short-term debt to capital while long-term debt ratio (LONG) is the total long-term debt divided by total capital. The explanatory variables include (PRE) profitability, (RSK) risk, and asset structure (AST), tax (TAX), size (SZE) and sales growth (GROW). The regression line model is use in this research and the result was a negative relationship between profitability and leverage. The results of prior studies show that higher profits increase the level of internal financing (Titman and Wessels 1988; and Barton 1989).Profitable banks accumulate internal reserves and this enables them to depend less on external funds. The results of this study show that profitability, corporate tax, 
growth, asset structure and bank size influence bank's financing or capital structure decision. The significant finding of this study is that more than 87 percent of the banks, assets are financed by debts and out of this shortterm debt appear to constitute more than three quarters of the capital of the banks. This highlights the importance of short-term debts over long-term debts in Ghanaian banks financing.

Pal and Soriya (2012) suggested that intellectual capital (IC) performance of Indian pharmaceutical and textile industry. The data was gathered from the 105 pharmaceutical companies and 102 textile companies. Dependent variables used in this study includes MB (market to book value), ROA (return on Asset), ATO (asset turnover ratio) and ROE (return on equity), independent variables are PC, DER, VAIC and sales. Correlation and regression analysis were conducted to find the results. The use of $\mathrm{MB}$ as the market valuation is also debatable because the market sentiments of the stakeholders may not always consider financial statements of the company. Yongvanich and Guthrie (2005) and Abeysekera and Guthrie (2005) classified intellectual capital into three components: external capital, internal capital and Human capital. Profitability measured by ROA clearly indicates that; profitability of the companies is reflected through intellectual capital performance. Findings of the study may be exercised by the managers to organize and utilize 'intellectual capital' to have additional profitable output. Return on equity is found to be positively influenced by 'intellectual capital' in case of pharmaceutical industry indicating that these firms are generating profits from every unit of shareholders' equity.

Abor (2007) examined that Industry classification and capital structure of Ghanaian SMEs. The analytical technique employed was regression. The dependent variables were LDR, SDR and TDR, independent variables in the model are defined as: industry dummy (IND) = constructed as a categorical variable; ( $=0$ if manufacturing, 1 if agriculture, 2 if construction and mining, 3 if hospitality, 4 if information and communication, 5 if pharmaceuticals and medical services, 6 if wholesale and retail trading, 7 if general business services). The control variables $(\mathrm{C})$ include firm age $=$ number of years, since commencement of business, firm size $=\log$ of total assets, asset structure $=$ fixed tangible assets divided by total assets (i.e. the proportion of total assets that has collateral value. It is a measure of the firm's collateral value), profitability $(\mathrm{PRE})=$ profit before interest and taxes/total assets, growth $($ GROW $)=$ average growth in sales. The outcomes of the research show which little as well as moderate businesses within the farming field show the very best funds framework as well as resource framework or even security worth, since the at wholesale prices as well as list industry business possess the lowermost financial debt percentage as well as resource framework. The actual regression outcomes shows that farming, pharmaceutical drug as well as healthcare sectors rely much more upon long-term (LTD) as well as short-term financial debt (short term debt) compared to the actual production field. The outcomes additionally display how the building as well as exploration business is actually not as likely in order to rely on shortterm financial debt (STD), whilst resort as well as food rely much more upon long term financial debt (LTD) and less upon short-term financial.

Chen (2009) Impact associated with funds framework as well as functional danger upon success associated with life insurance coverage business within Taiwan. Staking and Babbel (1995) supported the hypothesis found by Modigliani and Miller. Jou (1999) found that value of a firm initially increasing with financial leverage and then falling with financial leverage.

Komnenic and Pakrajcic (2012) purpose of their paper was to empirically investigate the impact of intellectual capital (IC) on organizational performance as well as to identify the IC components that may be the drivers of the traditional indicators of business success. Dependent variables are used in this research (HEC) Human capital efficiency and (SCE) structural capital efficiency and independent variables are (ROA) return on asset, (ROE) return on equity and control variable were (CEE) capital employed efficiency. Regression results of this study reveal that human capital is positively associated with all three corporate performance measures. The hypothesis regarding a positive association between structural capital and MNCs' profitability and productivity has been confirmed only partially since the results indicate that the structural capital variable shows a statistically significant and positive relationship only with the performance measure return on equity.

Pratheepkanth (2011) conducted a study his finding regarding the capital structure (CS) and its impact on financial performance during 2005 to 2009 of business organizations in Sri Lanka. The result of research validated a negative relationship between capital structure (CS) and financial performances of the Sri Lankan companies.

The arguments of prior researchers have well-balanced views on the determination of capital structure and firm performance. This study attempts to seek the extant up to which capital structure has affected the corporate performance particularly banking sector of Jordan.

\section{Methodology}

To investigate the impact of capital structure on banking performance in Jordan, this study is conducted by using the methodologies adopted in earlier research work on this issue. As other studies have discussed these relationships, conceptual frame work of this study is based on deduction method and for analysis of data collected from secondary sources quantitative techniques were employed. Descriptive statistics, correlation matrix and regression models are generally used for analysis of data. Methodology had been adopted to get the objectives, which is analyzing the changes in debt level towards affecting the firm 
performance. The data for the study is collected from financial statement of listed banks, website of Amman Stock Exchange (ASE) and Central bank of Jordan (CBJ).

\subsection{Variables Description and Hypotheses}

The following variables are used: Total Debt to Total Equity Ratio (DER), and Total Debt to Total Funds Ratio as independent variables, while dependent variables are Return on Equity (ROE), Return on capital employed (ROCE), Net profit ratio (NP) and Net Interest Margin (NIM).

The following hypotheses were formulated for the study:

H1. There is a significant impact of debt to equity on Net Profit.

H2. There is a significant impact of debt to equity on Return on Capital Employed.

H3. Debt to Equity has a significant impact on Return on Equity.

H4. Debt to Equity has a significant impact on Net Interest Margin.

H5. There is a significant impact of debt to total funds on Net Profit.

H6. There is a significant impact of debt to total funds on Return on Capital Employed.

H7. Debt to total funds has a significant impact on Return on Equity.

H8. Debt to total funds has a significant impact on Net Interest Margin.

\subsection{Data and Sample}

The population of the study is made up of 12 Commercial banks listed on (ASE). The data obtained from the published financial statements of these banks were tabulated and analyzed using multiple regression models. This statistical technique is used because the study seeks to establish if there is a relationship between capital structure and bank performance

\subsection{Model Specification}

The study employs Net profit, Return on Capital Employed, Return on Equity an Net Interest Margin as the dependent variables, and measures of bank performance. The independent variables in the study are Total Debt to Total Funds and Total Debt to Total Equity. Multiple regression models are used to find out the association between capital structure and bank performance in the context of Jordan. Four regression models are formulated to check the relationship between capital structure and banking performance. The general model for this study is represented by;

$\mathrm{P}=\mathrm{f}(\mathrm{CS})$

Which shows performance is the function of capital structure.

Where;

$\mathrm{P}=$ performance

$\mathrm{CS}=$ Capital structure
Performance is measured with the help of four ratios namely Net Profit, Return on Capital Employed (ROCE), Return on Equity (ROE and Net Interest Margin (NIM). Capital Structure is measured through Debt/Equity ratio and Debt to total funds ratio. Therefore, the regression model will be formulated in the following Equations;

Model 1

$\mathrm{NP}=\hat{\mathrm{a}} 0+\mathrm{a} 1 \mathrm{x} 1$

$\mathrm{NP}=\hat{\mathrm{a}} 0+\hat{\mathrm{a}} 1 \mathrm{x} 2$

Model 2

$\mathrm{ROCE}=\hat{\mathrm{a}} 0+\hat{\mathrm{a}} 1 \mathrm{x} 1$

$\mathrm{ROCE}=\hat{\mathrm{a}} 0+\mathrm{a} 1 \mathrm{x} 2$

Model 3

$\mathrm{ROE}=\hat{\mathrm{a}} 0+\mathrm{a} 1 \times 1$

$\mathrm{ROE}=\hat{\mathrm{a} 0} 0+\hat{\mathrm{a}} 1 \times 2$.

Model 4

$\mathrm{NIM}=\hat{\mathrm{a}} 0+\hat{\mathrm{a}} 1 \mathrm{x} 1$

$\mathrm{NIM}=\hat{\mathrm{a}} 0+\mathrm{a} 1 \times 2$

Where;

$\mathrm{X} 1=$ Debt/Equity ratio

$\mathrm{X} 2=$ Debt to Total Funds ratio

$\mathrm{NP}=$ Net Profit

â $0=$ Constant

ROCE $=$ Return on Capital Employed

$\mathrm{ROE}=$ Return on Equity

$\mathrm{NIM}=$ Net Interest Margin

\section{Result Discussions}

\subsection{Descriptive Statistics}

Table 1 provides a summary of the descriptive statistics for the dependent and independent variables for the sample banks. It shows that over the period under study, the profitability ratios measured by net profit, return on capital employed, return on equity and net interest margin averaged $8.9 \%, 14.8 \%, 9.5 \%$ and $4.9 \%$ respectively. The debt/equity ratio stood at $825.2 \%$ and debt to total funds averaged $88.7 \%$. This indication that approximately $89 \%$ of total assets in the banking sector of Jordan are represented by debt, confirming the fact that banks are highly geared institutions. The maximum and minimum values for debt/equity ratio indicate that the debt/equity composition varies substantially among the listed banks in Jordan.

Table 1: Summary of Descriptive Statistics

\begin{tabular}{llllll}
\hline & $\mathbf{N}$ & Minimum & Maximum & Mean & $\begin{array}{l}\text { Std. } \\
\text { Deviation }\end{array}$ \\
\hline $\begin{array}{l}\text { Net profit } \\
\text { Return on }\end{array}$ & 60 & -3.6 & 17.36 & 8.8789 & 5.90755 \\
$\begin{array}{l}\text { Capital } \\
\text { Employed } \\
\text { Return on }\end{array}$ & 60 & 9.32 & 25.42 & 14.8218 & 5.16101 \\
$\begin{array}{l}\text { Equity } \\
\text { Net Interest } \\
\text { Margin }\end{array}$ & 60 & 3.49 & 8.22 & 49070 & 1.73385 \\
$\begin{array}{l}\text { Debt/Equity } \\
\text { Ratio }\end{array}$ & 60 & 182.25 & 1535.88 & 825.1531 & 801.59839 \\
$\begin{array}{l}\text { Debt to } \\
\text { Total Funds }\end{array}$ & 60 & 77.48 & 95.39 & 88.6591 & 6.84658 \\
\hline
\end{tabular}




\subsection{Regression Analysis}

Table 2: predictors of Profitability - Model Summary1

\begin{tabular}{llllll}
\hline Model & $\begin{array}{l}\text { Dependent } \\
\text { Variable }\end{array}$ & $\mathbf{R}$ & $\mathbf{R}^{2}$ & $\begin{array}{l}\text { Adjusted } \\
\text { R Square }\end{array}$ & $\begin{array}{l}\text { Std. Error of } \\
\text { the Estimate }\end{array}$ \\
\hline 1 & NP & $0.370 \alpha$ & 0.137 & 0.029 & 5.82134 \\
2 & ROCE & $0.388 \alpha$ & 0.150 & 0.044 & 5.04167 \\
3 & ROE & $0.328 \alpha$ & 0.107 & -0.004 & 18.54840 \\
4 & NIM & $0.661 \alpha$ & 0.437 & 0.367 & 1.37944 \\
\hline
\end{tabular}

\section{a. Predictors: (constant), Debt/Equity Ratio}

The $\mathrm{R}^{2}$ values of $0.137,0.150,0.107$, and 0.437 which are in Table 2 denotes that $13.7 \%, 15 \%, 10.7 \%$, and $43.7 \%$ of the observed variability in NP, ROCE, ROE, and MIN is explained by the variability in the independent variable of Debt/Equity ratio. The $\mathrm{R}^{2}$ values indicate that there may be number of variables which can have impact on profitability other than the Dept/Equity ratio. This area indicates as a scope for future research.
Table 3: Predictors of profitability - Model summary11

\begin{tabular}{llllll}
\hline Model & $\begin{array}{l}\text { Dependent } \\
\text { Variable }\end{array}$ & $\mathbf{R}$ & $\begin{array}{l}\text { R } \\
\text { Square }\end{array}$ & $\begin{array}{l}\text { Adjusted } \\
\text { R Square }\end{array}$ & $\begin{array}{l}\text { Std. Error } \\
\text { of the } \\
\text { Estimate }\end{array}$ \\
\hline 1 & NP & $0.711^{\mathrm{a}}$ & 0.505 & 0.443 & 4.40927 \\
2 & ROCE & $0.561^{\mathrm{a}}$ & 0.314 & 0.229 & 4.53314 \\
3 & ROE & $0.246^{\mathrm{a}}$ & 0.061 & -0.057 & 19.02977 \\
4 & NIM & $0.879^{\mathrm{a}}$ & 0.773 & 0.744 & 0.87648 \\
\hline
\end{tabular}

b. Predictors: (Constant), Debt to Total Funds Ratio

Table 3 shows that Debt to Total Funds ratio is having impact of $50.5 \%$ and $77.3 \%$ on Net profit and Net Interest Margin respectively. This indicates that debt to total funds composition is the major determining factor of Net profit and Net Interest Margin of listed banks in Jordan. Only $6.1 \%$ of variations in Return on Equity are explained by the variations in debt to total funds. The remaining $93.9 \%$ is influenced by factors other than debt to total funds.

Table 4: coefficient for predictors of performance

\begin{tabular}{|c|c|c|c|c|c|}
\hline \multirow{2}{*}{ Models } & \multicolumn{2}{|c|}{ Unstandardized Coefficients } & Standardized Coefficients & \multirow{2}{*}{ t-value } & \multirow{2}{*}{ Sig } \\
\hline & B & Std.Error & Beta & & \\
\hline \multicolumn{6}{|l|}{$1-\mathrm{Np}$} \\
\hline Constant & 12.474 & 3.685 & & 3.385 & 0.010 \\
\hline $\mathrm{D} / \mathrm{E}$ & -0.004 & 0.004 & -0.370 & -1.126 & 0.293 \\
\hline Constant & 63.232 & 19.083 & -0.711 & 3.313 & 0.011 \\
\hline $\mathrm{D} / \mathrm{TF}$ & -0.613 & 0.215 & & -2.856 & 0.021 \\
\hline \multicolumn{6}{|l|}{ 2-ROCE } \\
\hline Constant & 18.113 & 3.194 & & 5.670 & 0.000 \\
\hline $\mathrm{D} / \mathrm{E}$ & -0.004 & 0.003 & -0.388 & -1.189 & 0.268 \\
\hline Constant & 52.286 & 19.620 & & 2.665 & 0.029 \\
\hline $\mathrm{D} / \mathrm{TF}$ & -0.423 & 0.221 & & -1.915 & 0.092 \\
\hline \multicolumn{5}{|l|}{ 3-ROE } & 0969 \\
\hline Constant & -0.471 & 11.741 & & -0.04 & $\begin{array}{l}0.909 \\
0.355\end{array}$ \\
\hline $\mathrm{D} / \mathrm{E}$ & 0.012 & 0.012 & 0.328 & 0.981 & 0.430 \\
\hline Constant & 68.490 & 82.362 & -0.246 & 0.82 & 0.493 \\
\hline $\mathrm{D} / \mathrm{TF}$ & -0.665 & 0.926 & & -0.718 & 0.493 \\
\hline \multicolumn{6}{|l|}{ 4-NIM } \\
\hline Constant & 6.793 & 0.873 & & 7.780 & 0.000 \\
\hline $\mathrm{D} / \mathrm{E}$ & -0.002 & 0.001 & $\begin{array}{r}-0.661 \\
-0.879\end{array}$ & -2.494 & 0.037 \\
\hline Constant & 24.645 & 3.793 & -0.879 & 6.497 & 0.000 \\
\hline $\mathrm{D} / \mathrm{TF}$ & -0.223 & 0.043 & & -5.217 & 0.001 \\
\hline
\end{tabular}

At the above models $t$ values were found to be significant in the model 4 and model 1 for the independent variable of debt to total funds. From the above mentioned table it is crystal clear that negative association was found between all the independent and dependent variables except the association between Debt Equity ratio and Return on Equity.

\subsection{Hypotheses Testing}

\begin{tabular}{llll}
\hline No & Hypotheses & Results & Tools \\
\hline H1 & $\begin{array}{l}\text { There is a significant impact of } \\
\text { debt to equity on Net profit }\end{array}$ & Rejected & Regression \\
H2 & $\begin{array}{l}\text { There is a significant impact of } \\
\text { debt to equity on Return on }\end{array}$ & Rejected & Regression \\
\hline
\end{tabular}

Capital Employed

H3 Debt to equity has a significant impact on Return on Equity

H4 Dept to Equity has a significant impact on Net Interest Margin

H5 There is a significant impact of debt to total funds on Net profit

There is a significant impact of debt to total funds on Return on Capital Employed

Debt to total Funds has a

H7 significant impact on Return on Equity

Debt to total funds has a

H8 significant impact on Interest Accepted Regression Margin
Rejected Regression

Accepted Regression

Accepted Regression

Rejected Regression

Rejected Regression 


\section{Conclusion}

This study examined the impact of capital structure on profitability in Jordanian banks. The study covered 12 listed banks on Amman Stock Exchange (ASE) over the period of 2007 to 2011 and the major findings of the study are summarized below:

Total debt was found to be significant in determining net profit and return on capital employed in the banking industry of Jordan. The mean values of debt/equity ratio and debt to total funds were $8250.15 \%$ and $88.66 \%$ respectively. The mean value of debt/equity ratio suggests that debt is 8.25 times higher than equity capital. The debt/equity ratio is normally safe up to 2 . It shows the fact that banks in Jordan depends more on debt (long-term loans) rather than equity capital. The mean value of debt to total funds ratio indicates $89 \%$ of the total capital of listed banks in Jordan is made up of debt. This has re-emphasized the fact that banks are highly levered institutions. Long-term debt and total debt were found to be insignificant in determining return on equity in the banking industry of Jordan. This means that deposits do not necessarily transit into enhancing return on equity in the banking industry of Jordan.

The $\mathrm{R}^{2}$ values were found to be significant for the impact of debt to total funds on net profit, debt/equity on net interest margin, and debt to total funds on net interest margin. But, no significant impact was found on the remaining dependent variables. Total debt has a major impact on net interest margin and net profit accounted for $77.3 \%$ and $50.5 \%$ respectively. The least amount of impact was found on return on equity $\left(\mathrm{R}^{2}=6 \%\right)$ by total debt. This reveals that remaining $94 \%$ is influenced by factors other than total debt. That is other factors are probably a better predictor of return on equity than total debt.

Banks generally play a crucial role in the economic development of every country. One critical decision banks face is the debt-equity choice. Among others, this choice is necessary for the profit determination of firms. What this means is that banks that are able to make their financing decision prudently would have a competitive advantage in the industry and thus making superior profits. Nonetheless, it is essential for us to recognize that this decision can only be wisely taken if banks know how debt policy influences their profitability. Therefore banks should take into view the following matters in order to increase their profitability;

1) An appropriate mix of capital structure should be adopted in order to increase the profitability of banks. Findings revealed that total debt contributed $50.5 \%$ in determining the net profit of the Banking Industry. That is in the case of higher debt, profitability will tend to decline. The reason behind this may be due to the high interest bearing securities engaged in the total debt. In addition to these an increase in the level of debt also increases the riskiness of banks. Therefore, banks should concern much on internal sources of financing in order to increase their profitability.

2) Top management of every banking firm should make prudent financing decision in order to remain profitable and competitive.

3) Banks in Jordan must not only be interested in mobilizing deposits but must also be concerned with utilizing these deposits effectively and efficiently. To achieve that, banks must set competitive lending rates that would not deter customers from accessing loans.

\section{References}

[1] Abor, J. (2005), "The Effect of Capital Structure on Profitability: An Empirical Analysis of Listed Firms in Ghana", The Journal of Risk Finance, Vol. 6 No.5.

[2] Abor, J. (2007). Corporate governance and Financing Decisions of Ghanian listed firms. Corporate Governance, 7, Journal of Risk Finance, 8(4), pp.364-379.

[3] Ahmad, Z., Hasan, N. M. A., \& Roslan, S. (2012). International Review of Business Research Papers, 8(5), 137-155.

[4] Amidu, M. (2007). Determinants of Capital Structure of Banks in Chana: an empirical approach. Baltic Journal of Management, 2(1), 67-79.

[5] Barton, S. L., Hill, N.C. \& Srinivasan, S. (1989). An empirical test of stakeholder theory Predictions of capital. Financial Management, 18(1), 36-44.

[6] Berger, A. N., (1995), "The Relationship in Banking-Tests of Market Power and Efficient Market Hypotheses", Journal of Money, Credit and Banking, 65 (3).

[7] Chen G, Firth M and Zhang WWW (2009), "The efficiency and profitability effects of China's modern enterprise restructuring programme", Asian Review of accounting, Vol. 16, No.1, pp.74-91.

[8] Grossman, S., \& Hart, O. (1986), The costs and benefit of ownership: A theory of vertical and lateral integration. Journal of Political Economy, 94, 691-719.

[9] Jou, D. G. (1999). Interest rate risk, surplus, leverage and market reward: an empirical study of Tawian life insurance industry. Journal of Management \& Systems, 6(3), 281-300.

[10] Kothari, C.R. (2004). Research Methodology Methods \& Techniques. Pp. 184-87.

[11] Mesquita, J.M.C., \& Lara, J. E. (2003). Capital Structure and profitability: the Brazilian case working paper. Academy of Business and Administration Sciences Conference, Vancouver, July 11-13.

[12] Modigliani, F. and Miller, M. (1958). The cost of capital: A correction. American Economic Review, 48(3), 261-97.

[13] Modigliani, F. and Miller, M. (1963), "Corporate income taxes and cost of capital: A Correction". American Economic Review, Vol. 53, pp 443-53.

[14] Niresh, J., Aloy, (2012), "Capital Structure \& Profitability in Srilankan Banks". Global Journal of Management \& 
Business Research, Vol. 12, pp.83-90.

[15] Pandey, I. M. (2009), Financial Management: Capital Structure Planning and Policy (pp. 332,333).

[16] Pal, K., \& Soriya, S. (2012). IC performance of Indian pharmaceutical and textile industry. Journal of Intellectual Capital, 13(1), 120-137.

[17] Phillips, \& Sipahioglu (2004). Performance implications of capital structure evidence from quoted UK organizations with hotel interests. The Servic industries Journal, 24(5), 3151.

[18] Pratheepkanth, P. (2011). Capital Structure and Financial Performance: Evidence from Selected Business Companies in Colombo Stock Exchange Sri Lanka. Journal of Arts, Science \& Commerce, 23.

[19] Ratio analysis.(2011).In Scribd Retrieved from http:// www.scribd.com/doc/24408725/Profitability - Ratios.
[20] Saad, N. M. (2010). Corporate Governance Compliance and the Effects to Capital Structure. International Journal of Economics and Financial, 2(1), 105-114.

[21] Staking, K.B., \& Babbel, D. F. (1995). The relation between capital structure, interest rate sensitivity and market value in the property-liability insurance industry. Journal of Risk and Insurance, 62(4), 690-718.

[22] Titman, S. and Wessels, R. (1988), "The Determinants of Capital Structure Choice", Journal of Finance, Vol.43 No. 1, pp.1-19.

[23] Taub, A. J. (1975), "Determinants of the Firm's Capital Structure", Review of Economics and Statistics, Vol. 57, pp. 410-416.

[24] Titman, S. (1984), "The effect of Capital Structure on a Firm's Liquidation Decisions", Journal of Financial Economics, Vol. 13, pp.137-51. 